\title{
The Unrecorded Cattle Business and the Provisioning of Social Utilities to Traders across the Nigeria-Cameroon Border
}

\author{
Salihu Zummo Hayatudeen ${ }^{1} \&$ Saidou Baba Oumar ${ }^{2}$ \\ ${ }^{1}$ Department of Economics, Modibbo Adama University of Technology, Yola, Nigeria \\ ${ }^{2}$ Department of Economics, The University of Bamenda, Bambili, Cameroon \\ Correspondence: Saidou Baba Oumar, Department of Economics, The University of Bamenda, Bambili, \\ Cameroon. E-mail: saidoubo@gmail.com
}

Received: July 29, 2015

Accepted: September 8, 2015

Online Published: January 25, 2016

doi:10.5539/ijef.v8n2p127

URL: http://dx.doi.org/10.5539/ijef.v8n2p127

\begin{abstract}
This paper analyzes the extent to which the unrecorded cattle business across the Nigeria-Cameroon border facilitates the provisioning of social utilities such as potable water, electricity, and healthcare to traders. It uses primary data obtained from 480 traders in 8 cattle market centers in Nigeria and Cameroon, and secondary data on the trade activities. Both the descriptive and inferential methods of data scrutiny are employed to achieve the aims of the investigation. Results of the paper reveal that the trade empowers only a few among the traders to easy access to social utilities in the study area due to misplacement of priorities and under-utilization of available resources in both countries. As a result, the paper recommends to Nigeria and Cameroon to reflect on how to enforce the proposals of the resources availability and vent-for-surplus theories of trade with little amendments based on their prevailing specificities to make the trade official.
\end{abstract}

Keywords: water, electricity, healthcare, livestock, cooperation, Nigeria, Cameroon

\section{Introduction}

The world has become a global village to the extent that it is very difficult nay impossible for countries to live in isolation with rigid frontiers. This gradual shrinking of frontiers is demonstrated by the proliferation of geo-politico-economic organizations based on cultural heritage or affinities to foster political and economic ambitions. The Economic Community of West African States (ECOWAS), Communauté Economique et Monétaire des Etats de l'Afrique Centrale (CEMAC), and Southern Africa Development Community (SADC), to mention just a few, are pertinent examples whose mission is to facilitate the movement of people, goods and services across national boundaries and promote regional security on the African continent. Being a member of ECOWAS, Nigeria influences the level of economic activities both within and outside the organization owing to her leading position among African economies. The World Bank (2015) ranks Nigeria the first African economy in 2014 based on her gross domestic product (GDP) of US $\$ 568.508$ billion.

Without exaggeration, Nigeria is surrounded by relatively small countries such as Benin Republic, Cameroon, Chad, and Niger Republic with which she undertakes heavy business activities that are mostly unrecorded in the balance of payments. In terms of market size, the Nigerian population of 183.5 million people is about 3 times the population of her four neighboring countries put together (World Population Review, 2015). As regards economic strength, Nigeria's gross domestic product (GDP) is about 17.50 times the GDP of Cameroon, 41 times the GDP of Chad, 65 fold the GDP of Benin, and 70 fold that of Niger Republic (World Bank, 2015). As regards economic and political freedom, Nigeria has a relatively high level of influence in designing her monetary policies and choosing her leadership as opposed to her neighboring countries whose monetary policies and leadership are heavily manipulated by France. And in order to fully understand the functioning of the unrecorded business activities between Nigeria and her neighboring countries using the Franc de la Communauté Financière de l'Afrique (FCFA) tight to Euro (€) through French Franc (FF) for monetary policies design by the French Treasury, France launched the Laboratoire d'Analyses et de Recherches Economiques Speciales (LARES) network as a macro-economic tool of analysis and study on the informal cross-border business taking place in the countries neighboring Nigeria.

The existence of the unrecorded cattle business across the Nigeria-Cameroon border preceded the birth of their 
present day official boundaries due to the socio-cultural realities tying the people of the two economies, thus making it a common phenomenon in the countries. Notwithstanding the popularity of this business, both Nigeria and Cameroon have failed to fully capture its economic gains since it continues to operate within the sphere of the underground economy. Although volumes of manufactured goods cross the border between Nigeria and her neighbors every day, cattle and food products are the most commonly traded commodities across the Nigeria-Cameroon border. For instance, the cattle sold are disseminated for slaughter everywhere in Nigeria to sustain the increasing need for meat use in the economy. In spite of this, the disequilibrium between the demand and supply for meat persists in the markets, thus making meat consumption very expensive since many people cannot afford eating it regularly in their meals. Also, it is noticed that many people partaking in the unrecorded cross-border cattle business are poor, hence the need to investigate the effects of the trade on the provisioning of social utilities to traders across the Nigeria-Cameroon border. The specific aims of the paper are:

1). To understand the socio-economic features of the unrecorded cattle business.

2). To analyze the organization of the unrecorded cattle business.

3). To discuss the benefits and problems associated with the unrecorded cattle business.

4). To assess the ability of the unrecorded cattle business in facilitating traders' access to social utilities, and

5). To propose ways of facilitating the trade between the countries.

The remainder of the paper is structured as follows. Section 2 covers the review of trade theories. Section 3 describes the methodology of the paper with special focus on the portrait of the study area, data and methods of analysis. Section 4 presents data analysis and discussion of results, whilst Section 5 gives the conclusion and recommendations of the paper.

\section{Review of Trade Theories}

This part of the paper explores the trade theories. The theories are examined from the angles of traditional or classical trade theories and new or contemporary trade theories. Traditional or classical trade theories support that the opening of trade between countries leads to increased gross domestic product (GDP) or national income of economies. According to the classical trade theories, trade liberalization enhances the welfare of people for the gains from specialization and exchange always generate higher output than expected with trade restrictions. To substantiate this claim, Smith (1776) simulates with the absolute advantage theory of trade (AATT) that countries are made up of households and their consumption behavior is similar to that of households or individuals. As a result, since every household finds it laudable to produce only some of its needs and to buy others from other producing households with the product it can sell, the same can apply to nations, implying that countries should engage in trade with each other.

With the comparative advantage theory of trade (CATT), Ricardo (1817) argues that trade between countries is always beneficial even if one of the trading countries is more productive than the other in all lines of production. The trading countries stand to benefit from trade provided that they have different opportunity costs for the production of the goods, meaning that trade between countries can also be a function of the comparative advantage in production lines. Ackello-Ogutu and Echessah (1997)'s examination of the unofficial exchange of goods across the Uganda-Kenya border proves that Uganda has a relative advantage in raw agricultural produces over Kenya which possesses a relative advantage in manufactured and processed goods over Uganda since the exports of Uganda to Kenya are beans, fish, and corn, whereas the exports of Kenya to Uganda concern beverages, textiles, hardware, flour and wheat. Furthermore, Heckscher (1919) and Ohlin (1933) advocate with the Heckscher-Ohlin factor-endowments theory of trade (FETT) that countries endowed with much capital are expected to manufacture and sell abroad capital intensive commodities and import labor intensive goods, while those that are rich in labor are expected to produce and sell overseas labor intensive commodities and import capital intensive merchandise. This proposal suggests that each country has to specialize in producing goods for which it has relative abundance of the factors needed in the production of these goods, meaning that trading countries have to take factor-endowments into account when opening their economies to the rest of the world (ROW).

Using the resources availability theory of trade (RATT), Kravis (1956) explains that a country may become involved in and focused on trading particular goods or resources with ROW owing to the availability of these resources. On the basis of this argument, it can be deduced that oil-exporting countries sell crude oil and not automobiles or electronics to ROW only because they have much oil deposits. This means that the availability of resources also conditions international trade. Looking at the dynamics of the informal livestock business between Nigeria and Cameroon, Hayatudeen et al. (2005) establish that most of the cattle traded in Adamawa State of 
Nigeria arrive from Cameroon, and this is so because of the factor endowment differences of the two countries that Balami (2007) understands within the framework of resources availability where abundant primary products are found in neighboring countries in contract to abundant petroleum products in Nigeria. Equally, Myint (1958) hypothesizes with the vent-for-surplus theory of trade (VSTT) that it is possible for a country to have a potential surplus of a productive capacity of some resources (land and labor) lying fallow and as such being excluded from trading activities with ROW. Against this background, it is anticipated that the opening of international trade on these resources would create opportunities for full utilization of the idle resources, new demand, and shunning under-employment of domestic resources in the country in question. This implies that trade with ROW also needs to explore and exploit available opportunities.

Finally, Grubber et al. (1967) and Posner (1961) explain respectively with the technological gap theory of trade (TGTT) and product cycle theory of trade (PCTT) that a considerable volume of trading activities among industrialized nations is mainly influenced by the spurring of new goods and new manufacturing process. And generally, this novelty offers the innovating country or company the opportunity to have, in the short-run, some monopoly power in the marketing of the product over other countries in the international market. Though short, the monopoly power may procure substantial returns and expand the resources base of the innovating country. Summing up, the bottom line of the traditional theories is that trade enhances the accumulation rate of extra wealth. Consequently, higher output growth is bound to occur in countries that are more opened to ROW, even if the rate of crime may also tend to increase: an aspect which has not been addressed by the trade theories examined above.

Yet some scholars maintain that trade does not necessarily lead to growth, trade liberalization may even impact growth negatively, while trade restrictions may enhance welfare under certain situations. Drawing from the existing hostile rivalry to capture overseas market for the sale of their raw materials, it is observed that ECOWAS member countries entertain low intra-regional official businesses with their peers due to artificial barriers such licenses, fees and restrictions on goods shipped across national borders. Therefore between 2007 and 2009, Nigeria's official transactions with her neighbors represent only $4 \%$ of her total exports value and $8 \%$ of her total exports volume (National Bureau of Statistics [NBS], 2010). In passing, Rodrik (2001)'s examination of policies of openness reveals that these latter impact on growth marginally. Besides this, Rigobon and Rodrik (2005)' s investigation based on a large set data from industrialized and developing economies shows that trading with ROW is harmful to social equality and revenue generation. The same study discloses that if, however, trade restrictions are used by domestic firms to acquire international market power and prevent entry and enlarge their market sphere, in that case affordable prices and higher output yield can transpire owing to economies of scale. Consequently, it is possible for the domestic firms to achieve dynamic gains because of the high costs on the entry and learning protecting them. These dynamic gains are similar to those associated with the amassing of material and human resources, and the creation of new ideas.

\section{Methodology}

This part of the paper clarifies the methodology employed to conquer the aims of the investigation. It begins by describing the study area prior to short discussions on the data, sample size and sampling technique, instruments of data compilation and method of data scrutiny.

\subsection{Portrait of the Study Area}

This paper focuses on the Grand Adamawa Region (GAR) that cuts across 8 cattle market centers in Nigeria and Cameroon. The market centers covered include Ganye, Konkol, Mubi, Ngurore, Adoumri, Garoua, Mokolo, and Ngaoundéré. GAR covers an area of about 206213 square kilometers [Km2] (Sa'ad, 1979; Carte Administrative du Cameroun [CAC], 2008 quoted in Institut National de la Statistique [INS], 2013, pp. 86-87). The estimated population of the area stands at 10.45 million people (National Population Commission [NPC], 2006; INS 2013, p. 85). A wave of cold air across November to February and hot air spanning March to June characterizes the climate of the area with an average temperature of $33.75^{\circ} \mathrm{C}$ and a rainfall average of 994.33 millimeters $(\mathrm{mm})$ per annum (Sa'ad, 1979). It is inhabited by the Nzanyi, Margi, Kilba, Higgi, Hausa, Gude, Fulani, Fali, Chamba, and Bura people amongst other social groups with main economic activities such as crop growing, breeding of domestic animals, fishing and commerce (Sa'ad, 1979). Although every community speaks a different mother tongue, Fulfulde and Hausa are mostly used as vernacular languages in GAR. The people in GAR believe in different religions including Paganism, Christianity and Islam.

\subsection{Data and Methods of Analysis}

Both primary and secondary data are used to reach the aims of the paper. Primary data are obtained through guided interviews, and personal remarks. Secondary data are gathered from NPC, NBS, and ISN documents. A 
purposive sampling technique is used to organize the data obtained from 4 market centers in Nigeria and 4 market centers in Cameroon. The structured interview is conducted with 60 cattle traders from each market center, summing up to 480 respondents chosen from Nigeria and Cameroon. The selected market centers are: Ganye, Konkol, Mubi, and Ngurore in Nigeria, and Adoumri, Garoua, Mokolo and Ngaoundéré in Cameroon. The number of traders interviewed per market center represents $12.50 \%$ of the sample as recapitulated in Table 1.

Table 1. Sample of traders from the market centers of the Nigeria-Cameroon cross-border cattle business

\begin{tabular}{llcc}
\hline Areas & Market centers & Respondents & Percentage $(\%)$ \\
\hline \multirow{3}{*}{ Nigeria } & Ganye & 60 & 12.50 \\
& Konkol & 60 & 12.50 \\
& Mubi & 60 & 12.50 \\
& Ngurore & 60 & 12.50 \\
& Adoumri & 60 & 12.50 \\
& Garoua & 60 & 12.50 \\
& Mokolo & 60 & 12.50 \\
& Ngaoundéré & 60 & 12.50 \\
\cline { 2 - 4 } & Total & 480 & 100 \\
\hline
\end{tabular}

Source: Authors.

To achieve the aims of the paper, the descriptive and inferential tools of data scrutiny are used. The descriptive tools employed include tables, simple percentages and charts, while the inferential instrument utilized is the Pearson Chi-square $(\chi 2)$ statistic for independence to test at $5 \%$ level of tolerance stated hypotheses of the inquiry. Also, EXCEL software package of data analysis is used to calculate the expected (theoretical) frequencies based on the observed (actual) frequencies generated from the primary data.

\section{Data Analysis and Discussion of Results}

This part of the paper analyzes the data and discusses the results. It envisages addressing the specific aims of the enquiry under different headlines.

\subsection{Socio-Economic Features of the Unrecorded Cross-border Cattle Business}

Table 2 gives a synopsis of some socio-economic features of the unrecorded cattle business across the Nigeria-Cameroon border. It shows that all the people involved in the trade are males; the currency used to buy cattle is Naira (N) in Nigeria and FCFA in Cameroon, exclusively. Also, it displays that the trade stands as the main occupation to $73.54 \%$ of the respondents, and about $69 \%$ of the traders duly pay their taxes to the government, while the remaining $31 \%$ avoid tax payment with the complicity of tax officials. Furthermore, it explains that over $81.45 \%$ of traders patronize parallel foreign exchange market to shun bureaucratic processes and social costs attached to the official foreign exchange market. Finally, it indicates that $65.41 \%$ of cattle buyers in the market centers reside in the southern parts of Nigeria or Cameroon, and $96.25 \%$ of the traders conclude their market transactions on cash and carry basis. Table 2 recapitulates the discussion.

Table 2. Socio-economic features of the unrecorded cattle business

\begin{tabular}{|c|c|c|c|c|c|c|c|c|c|c|c|c|c|c|}
\hline Features & M & $\mathrm{F}$ & $\mathrm{N}$ & $\mathrm{S}$ & N & FCFA & $\mathrm{O}$ & $\mathrm{B}$ & $\mathrm{G}$ & $\mathrm{P}$ & $\mathrm{C}$ & $\mathrm{Cr}$ & $\mathrm{Mn}$ & $\mathrm{Sec}$ \\
\hline Gender of traders & 480 & 0 & - & - & - & - & - & - & - & - & - & - & - & - \\
\hline Buyer residence & - & - & 166 & 314 & - & - & - & - & - & - & - & - & - & - \\
\hline Buy currency for seller & - & - & - & - & - & 1 & - & - & - & - & - & - & - & - \\
\hline Buy currency for buyer & - & - & - & - & 1 & - & - & - & - & - & - & - & - & - \\
\hline Exchange rate regime & - & - & - & - & - & - & 89 & 391 & - & - & - & - & - & - \\
\hline Tax payment & - & - & - & - & - & - & - & - & 332 & 148 & - & - & - & - \\
\hline Payment mode & - & - & - & - & - & - & - & - & - & - & 462 & 17 & - & - \\
\hline Employment strength & - & - & - & - & - & - & - & - & - & - & - & - & 353 & 127 \\
\hline Percentage $(\%)$ & 100.00 & 0 & 34.58 & 65.41 & 100.00 & 100.00 & 18.54 & 81.45 & 69.16 & 30.83 & 96.25 & 3.54 & 73.54 & 26.45 \\
\hline
\end{tabular}

Source: Authors.

Note. M: Male, F: Female, N: North, S: South, O: Official, B: Parallel, G: Government, P: Private, C: Cash and carry, Cr: Credit, Mn: Main, Sec: Secondary. 


\subsection{Cattle Market Organization and Mode of Cattle Transportation across the Border}

The cattle market that sustains the cross-border cattle business between Nigeria and Cameroon is a weekly phenomenon organized around three main actors: the sellers, middlemen (Dilaali), and buyer. The buyer group is structured into well-organized traders made up of big traders, petty traders having contact with security officials, less-organized traders consisting of petty traders having limited contact with security officials, and sporadic or unorganized traders harboring traders with dual citizenship of both countries. The Dilaali plays a pivotal role in all transactions concluded in the market by facilitating exchange between trading parties and guaranteeing that the cattle being traded is not stolen. A commission known as Laada is usually paid to the Dilaali by the buyer at the purchase time and by the seller at market closure for the services rendered in the buying and selling of the cattle. Figure 1 offers a simple model of the cattle market organization.

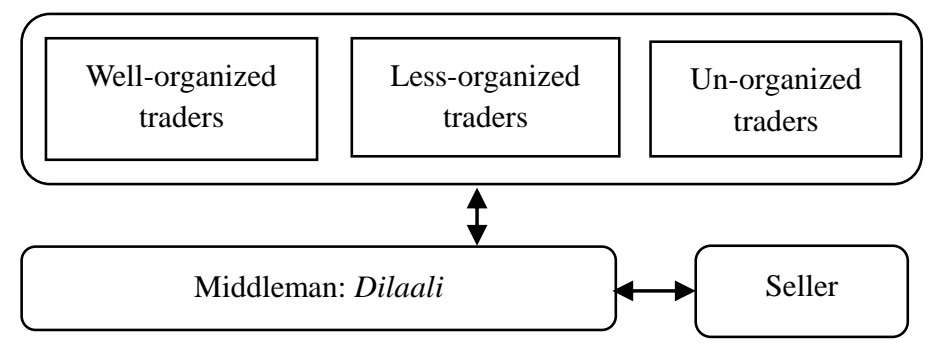

Figure 1. Organization of the cattle market

Source: Authors.

Table 3 shows the mode of transportation mostly used by traders to convey the cattle to the market. It indicates that $69.37 \%$ of the respondents transport the cattle from one market to the other through bush tracks, $25.62 \%$ of them use highways; while 5\% move the cattle through rivers. A careful examination of the statistics explains that bush tracks are highly patronized by the traders as a way of shunning custom officials at control posts on the highways. Conversely, rivers are less patronized by the traders because of the high risk associated with this mode of transportation.

Table 3. Mode of cattle transit across the border

\begin{tabular}{lcc}
\hline Transit modes & Respondents & Percentage $(\%)$ \\
\hline Bush track & 333 & 69.37 \\
River & 24 & 5.00 \\
Highway & 123 & 25.62 \\
Total & 480 & 100 \\
\hline
\end{tabular}

Source: Authors.

\subsection{Benefits and Problems Associated with the Unrecorded Cross-Border Cattle Business}

The practice of the unrecorded cattle business across the Nigeria-Cameroon border gives birth to advantages and disadvantages as well. The extent to which traders in the study assess the consequences of the phenomenon is presented in Table 4. It shows that $71.87 \%$ of the respondents depend on the trade for a living, $25.62 \%$ of them perceive the trade as a tool for social cohesion between people of the countries, while only $2.50 \%$ of the sample believes in the trade as an instrument for boosting international cooperation and the balance of payments of the countries. In addition, it reveals that only $10.83 \%$ of the respondents are worried about the corrupt practices besieging the trade as opposed to $29.37 \%$ and $59.79 \%$ of them who respectively complain about the bad condition of roads and insecurity in the shipment of cattle to the destination market centers. The low percentage of traders' awareness about the international cooperation benefit of the trade and the havoc of corrupt practices surrounding the trade is associated with the neglect of the two countries in making the trade official. In contrast, the high percentage of traders' assessment towards the trade being a source of livelihood and being obstructed by insecurity and the presence of many roadblocks on the highways mirrors respondents' selfish interest. 
Table 4. Consequences of the unrecorded cross-border cattle business

\begin{tabular}{llcc}
\hline Consequences & Variables & Respondents & Percentage $(\%)$ \\
\hline \multirow{4}{*}{ Benefits } & International cooperation & 12 & 2.50 \\
& Source of income & 345 & 71.87 \\
& Social cohesion & 123 & 25.62 \\
& Total & 480 & 100 \\
\hline \multirow{5}{*}{ Problems } & Bad condition of roads & 141 & 29.37 \\
& Corruption and bribery & 52 & 10.83 \\
& Insecurity and roadblocks & 287 & 59.79 \\
\hline
\end{tabular}

Source: Authors.

\subsection{Traders'Access to Social Utilities and the Trade Ability to Provisioning of Social Utilities}

This part of the paper discusses traders' access to social utilities and tests the ability of the unrecorded cross-border business in facilitating their access to those utilities at $5 \%$ level of significance using the non-parametric $\chi 2$ statistic. The categorical variables considered in the analysis include social utilities and traders' responses. The social utilities are categorized into potable water, electricity, and healthcare, while the responses are classified into yes or no.

Table 5 displays the responses of traders on the access to social utilities in the area of study. It displays that $54.37 \%$ of the respondents lack access to social utilities. Among the $45.62 \%$ of respondents who claim to have access to social utilities, below $40 \%$ of them have potable water, electricity, and healthcare services. The low percentage of traders having access to social utilities is associated with the general situation of priority misplacement and under-utilization of available resources in developing countries, hence the relevance of the proposals put forward by VSTT of Kravis (1956) and RATT of Myint (1958).

Table 5. Traders' responses to access to social utilities

\begin{tabular}{lccc}
\hline Social utilities & \multicolumn{3}{c}{ Responses } \\
\cline { 2 - 4 } & Yes & No & Total \\
\hline Potable water & $85(38.81)$ & $26(74.32)$ & $279(58.12)$ \\
Electricity & $56(25.57)$ & $41(15.70)$ & $82(17.08)$ \\
Healthcare & $78(35.61)$ & $261(54.37)$ & $119(24.79)$ \\
Total & $219(45.62)$ & & $480(100)$ \\
\hline
\end{tabular}

Source: Authors.

Note. Figures in brackets represent percentages.

To investigate the ability of the unrecorded cross-border cattle business in the provisioning of social utilities using the $\chi 2$ statistic, traders are solicited to tell whether or not the trade has facilitated their access to potable water, electricity and healthcare. The responses, as obtained from the traders and presented in Table 5, correspond to the observed (actual) frequencies of the sample about the inquiry. To run the test two hypotheses are developed as follows:

Null hypothesis- $\mathrm{H}_{0}$ : The unrecorded cattle business across the Nigeria-Cameroon border does not facilitate traders' access to social utilities.

Alternative hypothesis- $\mathrm{H}_{1}$ : The unrecorded cattle business across the Nigeria-Cameroon border facilitates traders' access to social utilities.

Given the observed frequencies of the sample, the corresponding expected (theoretical) frequencies are calculated using the formula in equation (1). The $\chi 2$ statistic formula converting the sample frequencies into a test statistic is given in equation (2). The formula for computing the degree of freedom (dv) to take into account while conducting the test is specified in equation (3), whilst the level of tolerance for the test is put at $\alpha=5 \%$.

$$
\begin{gathered}
f_{e}=\frac{\left(\sum_{r i}\right)\left(\sum_{c i}\right)}{n} \\
\chi^{2}=\frac{\sum\left(f_{o_{i}}-f_{e_{i}}\right)^{2}}{f_{e_{i}}}
\end{gathered}
$$




$$
d v=(r-1) *(c-1)
$$

Where,

$f_{0}$ : Observed frequency of category $i$,

$\mathrm{f}_{\mathrm{e} i}$ : Expected frequency of category $i$

$\Sigma_{r i}$ : Summation of row $i$

$\Sigma_{c i}$ : Summation of column $\mathrm{i}$

$\mathrm{n}$ : Total number of sample frequencies,

r: Number of rows,

c: Number of columns.

To calculate $\chi 2$ statistic, possibility tables for the observed and expected frequencies of the sample need to be mingled in a single $\chi 2$ estimation contingency table and the exigencies of equation (1), equation (2) and equation (3) taken into account. The contingency tables for the observed frequencies, expected frequencies, and estimation are all given in the appendix. After computation of the statistic, the decision rule needs to be respected by comparing the computed $\chi^{2}$ value with the critical $\chi^{2}$ ( $\chi^{\mathrm{t} 2} 2$-Crit) value read from $\chi^{2}$ distribution table. The decision rule for $\chi^{2}$ statistic is to reject the null hypothesis if the value of $\chi^{2}$ (computed $\chi^{2}$ ) is greater than the value of $\chi \mathrm{t} 2$-Crit, that is, $\chi^{2}>\chi \mathrm{t} 2$ at a given $\mathrm{dv}$. On the contrary, the null hypothesis is accepted when evidence shows that the value of $\chi^{2}$ is less than or equal to the value of $\chi \mathrm{t} 2$-Crit, that is, $\chi 2 \leq \chi \mathrm{t} 2$ at a given $\mathrm{dv}$.

Based on equation (3) and equation (2), it follows from the information in Table 6 that at $\alpha=5 \%$ with $\mathrm{dv}=(3-$ $1)^{*}(2-1)=(2)^{*}(1)=2, \chi 2=40.077$ and $\chi \mathrm{t} 2-\mathrm{Crit}=5.999$. Consequently, since the $\chi 2$ is greater than the $\chi \mathrm{t} 2-\mathrm{Crit}$, that is, $\chi^{2}>\chi^{\mathrm{t} 2}(40.077>5.999)$, the null hypothesis that the unrecorded cattle business across the NigeriaCameroon border does not facilitate traders' access to social utilities is rejected, implying that the business assists some traders, though not much, in accessing potable water, electricity and healthcare in the study area.

Table 6. Recap of result of Pearson Chi-square statistic test

\begin{tabular}{lc}
\hline Variables & Entries \\
\hline $\mathrm{H}_{0}$ & Unrecorded cattle business across Nigeria-Cameroon border not facilitating traders' access to social utilities \\
$\mathrm{H}_{1}$ & Unrecorded cattle business across Nigeria-Cameroon border facilitating traders' access to social utilities \\
Command variable $(\mathrm{Cdv})$ & Social utilities \\
Category for Cdv & Potable water, electricity, healthcare \\
Option variable $(\mathrm{Ov})$ & Responses \\
Category for Ov & Yes, no \\
Row for Cdv & 3 \\
Column for Ov & 2 \\
Degree of freedom $(\mathrm{dv})$ & 2 \\
Significance level $(\alpha \%)$ & 5 \\
Sample size & 480 \\
$\mathrm{X}^{2}$ & 40.077 \\
$\mathrm{X}_{\mathrm{t}}^{2}$-Crit & 5.999 \\
Test confrontation & $\mathrm{X}^{2}>\mathrm{X}_{\mathrm{t}}^{2}$ \\
Verdict & Reject $\mathrm{H}_{0}$ \\
\hline
\end{tabular}

Source: Estimation.

\section{Conclusion and Recommendations}

Based on the analysis of the paper, it can be concluded that the unrecorded cross-border cattle business is an important business. It assists participants in securing job and means of living. It is also observed that the business has the potential to enhance the well-being of households seriously if the government intervenes fully in the area of security, and provision of social utilities at the border areas of the two countries. The Chi square test offers evidence against the null hypothesis that the unrecorded cattle business across the Nigeria-Cameroon border does not facilitate traders' access to social utilities, implying that the business empowers some traders in acquiring potable water, electricity and healthcare in the study area. Besides, the paper discerns that men dominate the unrecorded cross-border cattle business activities. Yet, the socio-economic advantage radiating 
from this business can be swiftly negated if the unwarranted trade barriers and infrastructural deficiency obstructing the free movement of people and merchandise across the boundaries of the two countries are not minimized. For instance, the police/immigration/military personnel at the various checkpoints often claim additional payments from traders more than the customs representatives do, and this makes the business more demanding and frustrating for traders. Thus, the following action plan is suggested. One, for the unrecorded cross-border cattle business to benefit people, the governments of Nigeria and Cameroon should joint hand together to have a common policy on cattle business. Two, the two countries should combine efforts to construct roads and bridges in their border areas to facilitate the transit of cattle across the border. Three, the governments of the two countries should provide security to traders across the borders to encourage people's participation in the trade. Four, traders should portray responsible behavior by shunning corrupt practices that impede the achievement of developmental macro-economic policy objectives of governments. Five, the two countries are encouraged to reinforce international cooperation by taking into consideration the proposals of the vent-for-surplus and resources availability theories of trade to move towards a progressive formalization of the trade between them.

\section{References}

Ackello-Ogutu, C., \& Echessah, P. N. (1997). Unrecorded cross-border trade between Kenya and Uganda: Implications for food security. Technical paper 59, AFR/SD and REDSO/ESA, SD publication series, United States Agency for International Development (USAID), Africa Bureau. Retrieved 11 February, 2015 from http://www.google.com/url?....unrecorded-cross-border-trade-between-kenya-and-uganda-mplications-for-f ood security\%2....bv.85761416,d.ZWU

Balami, D. H. (2007). Cross-border trade between Nigeria and her neighbours. A report submitted to network on cross-border trade, Paris, PRS, Laboratoire d'Analyse Régionale et d' Expertise Sociale (LARES).

Carte Administrative du Cameroon [CAC]. (2008).

Grubber, W., Metha, D., \& Vernon, R. (1967). The R \& D factor in international trade and international investment of United States industries. Journal of Political Economy, 75(1), 20-37. http://dx.doi.org/10.1086/259235

Hayatudeen, S. Z., Oumar, S. B., \& Gazali, K. A. Y. (2005). The dynamics of informal livestock cross-border trade between Nigeria and Cameroon. Maiduguri Journal of Arts and Social Sciences, 3(1).

Heckscher, E. F. (1919). The effect of foreign trade on the distribution of income. Ekonomisk Tidskriff, 497-512. Translated in American Economic Association (1949). Readings in the theory of international trade (Chapter 13, pp. 271-300). Philadelphia, PHA: Blakiston.

Institut National de la Statistique [INS]. (2013). Annuaire statistique du Cameroun. Yaoundé, YDE: INS. $\begin{array}{lllll}\text { Retrieved } & 18 & \text { January } & 2015 & \text { from }\end{array}$ http://www.stat.cm/downloads/annuaire/2013/Annuaire_statistique_2013.pdf

Kravis, I. B. (1956). Availability and influences on commodity composition of trade. Journal of Political Economy, 64(2), 143-155. http://dx.doi.org/10.1086/257769

Myint, H. (1958). The classical theory of international trade and the underdeveloped countries. Economic Journal, 63(270), 317-337. http://dx.doi.org/10.2307/2227598

National Bureau of Statistics [NBS]. (2010). Annual abstract of statistics 2010. Abuja, ABJ: NBS. Retrieved 26 August 2015

from http://www.nigerianstat.gov.ng/nbslibrary/nbs-annual-abstract-of-statistics/nbs-annual-abstract-of-statistics

National Population Commission [NPC]. (2006). 2006 population and housing census of the Federal Republic of Nigeria: National and state and housing tables. Priority tables (1). Abuja, ABJ: NPC. Retrieved 11 February 2015 from http://www.population.gov.ng/images/Priority\%20Tables\%20Volume\%20I-update.pdf

Ohlin, B. G. (1933). Interregional and international trade. Cambridge, CBG: Harvard University Press 1966.

Posner, M. V. (1961). International trade and technical change. Oxford Economic Papers, 13(3), 323-341.

Ricardo, D. (1817). On the principles of political economy and taxation (3rd ed., 1821). Kitchener, KTR, Canada: $\begin{array}{lllllll}\text { Batoche } & \text { Books } & \text { (2001). } & \text { Retrieved } & 26 & \text { August } & 2015\end{array}$ from http://www.socserv.mcmaster.ca/econ/ugcm/..../Principles.pdf

Rigobon, R., \& Rodrik, D. (2005). Rule of law, democracy, openness and income: Estimating the 
interrelationships. The Economics of Transition, 13(3), 533-564. http://dx.doi.org/10.1111/j.1468-0351.2005.00226.x

Rodrik, D. (2001). The global governance of trade as if development really mattered. New York, NY: United Nations Development Program, p. 41. Retrieved 26 August, 2015 from http://www.hks.harvard.edu/m-rcbg/research/d.rodrik_undp_global.governance.of.trade.pdf

Sa'ad, A. (1979). The development of Yola town. A paper presented at Mahmud Ribadu Square, Gongola State, Yola, YLA, Nigeria.

Smith, A. (1776). An inquiry in the causes and causes of wealth of the nations. Reprinted in 1976, United Kingdom, UK: Clarendon Press. http://dx.doi.org/10.1093/oseo/instance.00043218

World Bank. (2015). World development indicators database: Gross domestic product 2014. Retrieved 27 July, 2015 from http://www.databank.worldbank.org/data/download/GDP.pdf

World Population Review. (2015). Country populations 2015. Retrieved 28 August, 2015 from http://www.worldpopulationreview.com/countries

\section{Appendix A}

Possibility table of expected frequencies on traders' access to social utilities

\begin{tabular}{lccc}
\hline Social utilities & \multicolumn{3}{c}{ Responses } \\
\cline { 2 - 4 } & Yes & No & Total \\
\hline Potable water & 85 & 149 & 234 \\
Electricity & 61 & 26 & 87 \\
Healthcare & 98 & 61 & 159 \\
Total & 244 & 236 & 480 \\
\hline
\end{tabular}

\section{Appendix B}

Possibility table of expected frequencies on the ability of trade to provisioning of social utilities

\begin{tabular}{lccc}
\hline Social utilities & \multicolumn{3}{c}{ Responses } \\
\cline { 2 - 4 } & Yes & No & Total \\
\hline Potable water & 118.95 & 115.05 & 234 \\
Electricity & 44.22 & 42.77 & 87 \\
Healthcare & 80.82 & 78.17 & 159 \\
Total & 244 & 236 & 480 \\
\hline
\end{tabular}

\section{Appendix C}

Chi-square estimation table

\begin{tabular}{ccccc}
\hline Observed frequencies (fo) & Expected frequencies $(\mathrm{fe})$ & $\mathrm{D}=(\mathrm{fo}-\mathrm{fe})$ & $\mathrm{DS}=(\mathrm{fo}-\mathrm{fe})^{2}$ & $(\mathrm{DS} \div \mathrm{fe})$ \\
\hline 85 & 118.95 & -33.95 & 1152.60 & 9.689 \\
61 & 44.22 & 16.78 & 281.56 & 6.367 \\
98 & 80.82 & 17.18 & 295.15 & 3.651 \\
149 & 115.05 & 33.95 & 1152.60 & 10.018 \\
26 & 42.77 & -16.77 & 281.23 & 6.575 \\
61 & 78.17 & -17.17 & 294.80 & 3.771 \\
- & - & - & - & $\chi^{2}=\Sigma(\mathrm{DS} \div \mathrm{fe})$ \\
& - & - & - & $=40.077$ \\
\hline
\end{tabular}

D: Difference between fo and fe.

DS: Square of difference between fo and fe.

\section{Copyrights}

Copyright for this article is retained by the author(s), with first publication rights granted to the journal.

This is an open-access article distributed under the terms and conditions of the Creative Commons Attribution license (http://creativecommons.org/licenses/by/3.0/). 